\title{
RANCANG BANGUN SISTEM INFORMASI GEOGRAFIS KESESUAIAN LAHAN TANAMAN PADI GOGO (Oriza sativa L.) BERBASIS WEB ( STUDI KASUS : KECAMATAN SUKAJAYA, KABUPATEN BOGOR )
}

\author{
Brian Armadji*, Zainul Arham**, Iwan Aminudin***
}

\begin{abstract}
ABSTRAK
Kabupaten Bogor memiliki peran strategis bagi kemajuan pembangunan nasional, karena itu adalah ibukota negara bagian penyangga di sisi dekat dengan pangsa pasar hasil komoditas pertanian serta lembaga pendidikan pusat dan penelitian dan pengembangan berbasis pertanian. Sukajaya Kecamatan adalah salah satu kabupaten di Kabupaten Bogor. Sebagian besar mata pencaharian penduduk adalah bertani, sebanyak 9.170 rumah tangga pertanian (CBS, 2013). Selama lahan kering ini tersedia cukup luas dan pemanfaatannya untuk tanaman padi gogo tidak optimal, sehingga masa depan produksi padi gogo juga dapat digunakan sebagai andalan produksi beras nasional. Oleh karena itu, Sistem Informasi Geografis Kesesuaian Lahan Padi Gogo dapat mendukung semua pihak untuk mengetahui informasi tentang daerah yang cocok untuk budidaya Padi Gogo dan juga tentang kesesuaian menanam padi lahan dataran tinggi dan merekomendasikan pupuk untuk tanaman padi gogo yang, jika diterapkan, diharapkan mampu meningkatkan produksi padi gogo di negara itu untuk memenuhi kebutuhan masyarakat. Dalam penelitian ini, analisis spasial kesesuaian lahan berdasarkan persyaratan tanaman ditanam dengan metode pencocokan (matching) dan teknik overlay (overlay) model serikat. Dalam pengembangan sistem menggunakan Application Development Cepat (RAD) dengan notasi UML dan software dalam mendukung pelaksanaan menggunakan Opensource OpenGeo Suite dan PHP sebagai bahasa pemrograman dan menggunakan database MySQL. Hasil yang dicapai dalam bentuk sistem informasi geografis berbasis web yang meliputi beras tanah kesesuaian tanaman dataran tinggi, tanaman padi sampel uji titik data produksi dataran tinggi tanah dan pupuk rekomendasi pada setiap titik sampel.
\end{abstract}

\begin{abstract}
Bogor Regency has a strategic role for the progress of national development, because it is the state capital buffer on the side close to the market share of the results of agricultural commodities as well as central educational institutions and research and development based on agriculture. Sukajaya sub-district is one of the districts in the regency of Bogor. Most of the population livelihood is farming, as many as 9,170 agricultural households (CBS, 2013).
\end{abstract}


During this dry land available is quite extensive and its utilization for upland rice crop is not optimal, so that the future of upland rice production can also be used as a mainstay of the national rice production. Therefore, a Geographic Information Systems Land Suitability Rice Gogo can support to all parties in order to find out information about the area suitable for cultivation of Upland Rice and also about the suitability of land plant upland rice and recommend fertilizer for crops of upland rice which, if implemented, is expected to able to increase production of upland rice in the country to meet the needs of the community. In this study, spatial analysis of land suitability is based on the requirements of plants grown by the method of matching (matching) and engineering overlaying (overlay) model of union. In the development of systems using the Rapid Application Development (RAD) with UML notation and software in support of the implementation using Opensource OpenGeo Suite and PHP as the programming language and uses a MySQL database. Results achieved in the form of a web-based geographic information system that includes land suitability plant upland rice, upland rice crop production data point test samples of soil and fertilizer recommendations at each sample point.

Keywords : Web-based Geographic Information System, Land Suitability of Upland Rice Plants, Rapid Application Development ( RAD ) , UML , OpenGeoUnified Modelling Language (UML).

\section{PENDAHULUAN}

\section{Latar Belakang}

Secara geografis Kabupaten Bogor terletak antara $6^{\circ} 18^{\prime} 0^{\prime}$ - 6 6 $47^{\prime} 10^{\prime}$ ' Lintang Selatan dan $106^{\circ} 23^{\prime} 45^{\prime \prime}$ - $107^{\circ} 13^{\prime} 30^{\prime \prime}$ Bujur Timur, yang berdekatan dengan Ibukota Negara sebagai pusat pemerintahan, jasa dan perdagangan dengan aktifitas pembangunan yang cukup tinggi, memiliki luas $\pm 298.838,304$ Ha. Pembangunan pertanian dan kehutanan di Kabupaten Bogor mempunyai peran yang strategis untuk kemajuan pembangunan nasional, hal ini mengingat letak geografisnya, Kabupaten Bogor merupakan penyangga ibukota negara di samping dekat dengan pangsa pasar hasil komoditi pertanian dan kehutanan juga sebagai pusat institusi pendidikan dan penelitian serta pengembangan yang berbasis pertanian secara luas (Dinas Pertanian dan Kehutanan Kabupaten Bogor, 2010).

Kecamatan Sukajaya merupakan salah satu kecamatan di lingkungan Kabupaten Bogor, dengan jumlah penduduk \pm 59.096 jiwa. Sebagian besar mata pencaharian penduduk di Kecamatan tersebut adalah bertani, kendati luas lahan sebenarnya tidak memadai karena sebagian besar lahan diperuntukkan bagi kegiatan pertambangan, perkebunan dan ditetapkan sebagai kawasan hutan. Penduduk Desa Cisarua di Kecamatan Sukajaya sebagian besar masyarakatnya masuk dalam kelompok pra sejahtera. Kendati mayoritas penduduknya bermata pencaharian bertani, namun lahan yang dipergunakan untuk 
kegiatan persawahan hanya 133 Ha. Sementara $2.767 \mathrm{Ha}$, dikuasai oleh pengelola Taman Nasional Gunung Halimun dan Perum Perhutani. Desa Cileuksa, memiliki luas 1.175,6 Ha, dan sebagian besar dikuasai oleh Perum Perhutani dan PT. Nirmala Agung. Sedangkan lahan untuk kegiatan persawahan penduduk hanya tersisa $216 \mathrm{Ha}$ (Santosa et al., 2003).

Selama ini produksi padi nasional masih mengandalkan sawah irigasi, namun ke depan bila hanya mengandalkan padi sawah irigasi akan menghadapi banyak kendala. Hal tersebut disebabkan banyaknya lahan sawah irigasi subur yang beralih fungsi ke penggunaan lahan non pertanian, tingginya biaya pencetakan lahan sawah baru dan berkurangnya debit air. Dilain pihak lahan kering tersedia cukup luas dan pemanfaatannya untuk pertanaman padi gogo belum optimal, sehingga ke depan produksi padi gogo juga dapat dijadikan andalan produksi padi nasional. (Pujiharti et al., 2008).

Table 1. Produktivitas dan Persentase Peningkatan Padi Gogo Nasional selang lima tahun dari tahun $1970-2010$

\begin{tabular}{rcc}
\hline $\begin{array}{r}\text { Tah } \\
\text { un }\end{array}$ & $\begin{array}{c}\text { Produktivitas } \\
\text { (Ton/Ha) }\end{array}$ & $\begin{array}{c}\text { Persentase } \\
\text { Peningkatan }\end{array}$ \\
\hline 1970 & 1,11 & 0,0 \\
1975 & 1,28 & 15,3 \\
1980 & 1,4 & 9,4 \\
1985 & 1,75 & 25,0 \\
1990 & 2,09 & 19,4 \\
1995 & 2,17 & 3,8 \\
2000 & 2,29 & 5,5 \\
2005 & 2,56 & 11,8 \\
2010 & 2,87 & 12,1 \\
\hline
\end{tabular}

Setelah melihat beberapa penelitian tentang analisis dan evaluasi kesesuaian lahan yang telah dilakukan di bermacam macam wilayah, telah menjadi bukti bahwa analisis dan evaluasi lahan tersebut cukup membantu sebagian permasalahan pertanian tanaman pangan. Dengan adanya sistem informasi geografis analisis kesesuaian lahan diharapkan dapat membantu pemerintah, khususnya yang bergerak bidang pertanian untuk memberikan informasi mengenai kesesuaian lahan kepada masyarakaat. Tanaman padi gogo merupakan salah satu komoditas yang menjadi perhatian pemerintah karena tingkat konsumsi masyarakat akan padi gogo sangatlah tinggi. Melihat hal ini sistem informasi geografis analisis kesesuaian lahan berbasis web dapat bermanfaat dalam membantu pengembangan pertanian khususnya di Kecamatan Sukajaya, Kabupaten Bogor. Berdasarkan latar belakang tersebut peneliti tertarik untuk melakukan penelitian pada pembuatan skripsi dengan judul "Rancang Bangun Sistem Informasi Geografis Kesesuaian Lahan Tanaman Padi Gogo (Oryza sativa L.) Berbasis Web (Studi Kasus: Kecamatan Sukajaya, Kabupaten Bogor) $)^{6}$.

\section{METODE PENELITIAN}

Deskripsi lokasi dan tempat
penelitian dalam pengembangan
SIGKEJAG yaitu Dinas Pertanian dan
Kehutanan Kabupaten Bogor. Waktu
penelitian berlangsung pada bulan Juni -
Desember 2013. Dalam perancangan sistem
ini terdapat beberapa data yang diperlukan
diantaranya:

1. Data Spasial 
Data spasial dapat dilihat pada Tabel 2.

2. Data Tabulasi

a) Data Luas Tanam, Luas Panen, Produktivitas dan Produksi Padi Gogo dari tahun 2008 sampai 2011 di Kabupaten Bogor didapat dari Dinas Pertanian dan Kehutanan Kabupaten Bogor.

b) Data Produktivitas dan Persentase Peningkatan Padi Gogo Nasional selang lima tahun dari tahun 1970 2010 didapat dari Husin Moh Toha yang diolah dari data Biro Pusat Statistik.

Perangkat yang digunakan pada penelitian ini berupa perangkat keras dan perangkat lunak.

1. Perangkat Keras
a.Processor@1.60 Ghz
b. RAM $2 \mathrm{~Gb}$
c. Hardisk $320 \mathrm{~Gb}$
d. Monitor 12" resolusi 1366 x 768
e. Garmin GPS Map 76csx
f. Perangkat Uji Tanah Kering

2. Perangkat Lunak

a. Windows 7 Ultimate Service Pack 1.

b. OpenGeoSuite 3.0.1 sebagai Platform Web-Based.

c. ArcGIS 10.1 sebagai tools untuk analisis spasial.

d. Macromedia Dreamweaver 8 dan Mozilla Firefox 24.0 sebagai Text Editor dan Web Browser. e. Microsoft Office Visio sebagai tools untuk perancangan sistem dan pembuatan UML.

Dalam penelitian ini terdapat empat macam metode pengumpulan data yang digunakan, yaitu observasi, wawancara, studi pustaka, dan studi literatur sejenis.

\section{Observasi}

Observasi dilakukan untuk mendapatkan data-data mengenai analisis kesesuaian lahan di kecamatan Sukajaya Desa Cileuksa, Pasir Madang dan Cisarua di Kabupaten bogor.

Dalam pembangunan “ Sistem Informasi Geografis Kesesuaian Lahan Tanaman Jagung Berbasis Web (Studi Kasus : Kecamatan Sukajaya, Bogor )", penulis melakukan observasi pada lokasi penelitian dan instansi pemerintah yang terkait dan berkepentingan terhadap perencanaan pengelolaan pertanian dalam hal ini Dinas Pertanian dan Kehutanan Kabupaten Bogor

\section{Wawancara}

Wawancara dilakukan kepada Kepala Seksi Produksi Bidang Tanaman Pangan DISTANHUT. Hal ini dilakukan guna mengetahui prosedur serta kegiatan pengolahan data yang dilakukan sehingga dapat memberikan informasi dan data yang bersangkutan dengan penelitian.

\section{Studi Pustaka}

Kegiatan yang dilakukan adalah dengan cara membaca dan mempelajari buku-buku terkait analisis kesesuaian lahan serta mempelajari regulasi- 
regulasi terkait analisis kesesuaian lahan dan pengembangan sistem.

\section{Studi Literatur Sejenis}

Kegiatan ini dilakukan dengan cara membaca dan mempelajari karya ilmiah sejenis. Berikut literatur sejenis pendukung penelitian ini :

a. Evaluasi Kesesuaian Lahan Untuk Komoditas Padi Berdasarkan Pendekatan Pedo-Agroklimat Di Kabupaten Kutai Katanegara. Rudin Hamsyah (2009).

b. Analisis Kelayakan Finansial Usaha Tani Padi Sawah Pada Dua Ordo Kesesuaian Lahan di Kabupaten Donggala. Ambarwati N. M. (2002).

c. Evaluasi Kesesuaian Lahan Untuk Tanaman Padi Pada Areal Sawah Bukaan Baru dan Lama di Kenagarian Siguntur Kecamatan Sitiung, Kabupaten Dharmasraya. Benny Putra (2007).

Dalam analisis data kesesuaian lahan untuk tanaman jagung digunakan metode pencocokan (matching) terhadap seluruh parameter fisik kesesuaian lahan untuk penentuan kawasan penanaman jagung. Sebelum dilakukan pencocokan, pada setiap parameter dibuat kelas kesesuaian lahan. Adapaun kelas kesesuaian lahan yang digunakan dalam penelitian ini yaitu : lereng, ketinggian dari permukaan laut, tutupan lahan, curah hujan, suhu udara, kelembaban udara, tingkat keasaman, kandungan karbon (C-organik), kandungan fosfor, dan kandungan kalium.

Dalam analisis data kesesuaian lahan tanaman jagung, setelah proses overlay kemudian dilakukan tahapan pengkelasan ulang (reclass). Penentuan kelas kesesuaian lahan yang baru dari dua kelas kesesuaian lahan yang lama didasarkan pada tingkat kesesuaiannya. Kelas kesesuaian S1 hanya dibentuk oleh kelas S1 dan kelas S1. Apabila ada dua kelas kesesuaian yang berbeda, maka kelas kesesuaian yang baru adalah kelas kesesuaian yang lebih rendah. berikut adalah matriks penentuan kelas kesesuaian baru dari dua kelas kesesuaian yang berbeda

Table 2. Matriks Reclass Kelas Kesesuaian Lahan

\begin{tabular}{|c|c|c|c|c|}
\hline No. & Data Spasial & Tahun & Sumber & Keterangan \\
\hline 1 & $\begin{array}{l}\text { Peta Rupabumi Indonesia digital format shapefile } \\
\text { lembar 1109-342 }\end{array}$ & 2008 & $\begin{array}{c}\text { Badan Informasi } \\
\text { Geospasial }\end{array}$ & Data Sekunder \\
\hline 2 & $\begin{array}{l}\text { Peta Rupabumi Indonesia Digital format shapefile } \\
\text { lembar 1109-344 }\end{array}$ & 2008 & $\begin{array}{l}\text { Badan Informasi } \\
\text { Geospasial }\end{array}$ & Data Sekunder \\
\hline 3 & $\begin{array}{l}\text { Peta Administrasi Kecamatan Sukajaya format } \\
\text { drawing file }\end{array}$ & 2012 & $\begin{array}{l}\text { Bappeda Kab. } \\
\text { Bogor }\end{array}$ & Data Sekunder \\
\hline 4 & $\begin{array}{l}\text { Peta Curah Hujan, Suhu dan Kelembapan Udara } \\
\text { Kecamatan Sukajaya }\end{array}$ & 2014 & $\begin{array}{l}\text { BMKG Darmaga } \\
\text { Bogor }\end{array}$ & Data Sekunder \\
\hline
\end{tabular}


Table 3. Matriks Reclass Kelas Kesesuaian Lahan

\begin{tabular}{ccccc}
\hline $\begin{array}{c}\text { Kelas } \\
\text { Kesesuaian }\end{array}$ & S1 & S2 & S3 & N \\
\hline S1 & S1*1 & S2*2 & S3*3 & $\mathrm{N}^{* 4}$ \\
S2 & S2*2 & S2*2 & S3*3 & $\mathrm{N}^{* 4}$ \\
S3 & S3*3 & S3*3 & S3*3 & $\mathrm{N}^{* 4}$ \\
N & $\mathrm{N}^{* 4}$ & N*4 & N*4 & $\mathrm{N}^{* 4}$ \\
\hline
\end{tabular}

\section{Metode Pengembangan Sistem}

Penelitian ini menggunakan metode RAD berdasar pada teori Kendall \& Kendall (2003). Sedangkan tools yang digunakan adalah notasi UML menggunakan teori Whitten (2004) yang merupakan pemodelan berorientasi objek. Metode RAD terdiri dari tiga fase pengembangan yaitu:

\section{a. Perencanaan Syarat - syarat}

Merupakan sebuah tahap awal untuk suatu proyek, dimana pengguna sistem yaitu pihak Dinas Pertanian dan Kehutanan Kabupaten Bogor dan si pembuat sistem mengidentifikasi kebutuhan untuk memenuhi tujuan sistem informasi kesesuaian lahan tanaman jagung, mengidentifikasi kebutuhan informasi yang timbul dari tujuan tersebut, serta menentukan batasan-batasan sistem informasi geografis yang dibuat, kendala serta alternatif masalah. Fase ini membutuhkan keterlibatan intens dari kedua kelompok yaitu pihak si pembuat sistem dan Staf Dinas Pertanian dan Kehutanan Kabupaten Bogor bukan terletak pada penandatanganan pada proposal atau dokumen.
Dalam fase ini penulis dengan Staf DISTANHUT bertemu untuk mengidentifikasi tujuan sistem serta mengidentifikasi informasi kebutuhan yang ditimbulkan dari tujuan tersebut. Dalam pertemuan tersebut diperoleh perencanaan yang dibuat dalam Sistem Informasi Geografis Kesesuaian Lahan Tanaman padi gogo, yaitu :

- Pengumpulan Data dan Syaratsyarat Informasi, diantaranya observasi, wawancara dan studi kepustakaan.

- Identifikasi Masalah, meliputi analisis sistem berjalan dan analisis sistem usulan.

\section{b. Desain Workshop}

Merupakan tahap lanjutan dari tahap perencanaan kebutuhan, dimana dilakukan pengidentifikasian dari solusi alternative yang ada dengan pemilihan solusi terbaik. Fase ini merupakan fase untuk merancang dan memperbaiki yang dapat digambarkan sebagai workshop.

Setelah itu, melakukan proses desain yang dilanjutkan dengan merancang sistem informasi geografis dengan menggunakan UML. Dengan tahapan sebagai berikut :

- Membuat Diagram Use Case

- Membuat Skenario Use Case

- Membuat Diagram Aktivitas

- Membuat Diagram Kelas

- Membuat Mapping Diagram Kelas

- Membuat Diagram Sekuensi

- Membuat Perancangan Basis Data

- Membuat Desain Tampilan Sistem 


\section{c. Fase Implementasi}

Tahap ini terdiri dari dua tahapan, yaitu tahap pengimplementasian sistem ke dalam bahasa pemrograman (coding) dan tahap pengujian sistem oleh beberapa owner, analyst dan developer dengan tujuan apakah sistem yang dibangun sudah berjalan dengan baik pada saat pengoperasiannya atau masih terdapat kesalahan (error).

\section{HASIL DAN PEMBAHASAN}

Overlay tiap peta dilakukan secara bertahap untuk menghindari akumulasi kesalahan. Berikut gambar proses analisis overlay (Gambar 1). Data hasil pengujian lapangan dapat dilihat pada tabel 1 dan tabel 2. Peta kesesuaian lahan padi gogo untuk wilayah Bogor (gambar 2). Hasil penggunaan diagram use case dapat dilihat pada Gambar 3. Mapping diagram kelas dapat dilihat pada Gambar 4. Serta desain tampak muka dapat dilihat pada Gambar 5.

\section{KESIMPULAN DAN SARAN}

\section{Kesimpulan}

Dari hasil penelitian yang telah dilakukan, dapat diambil kesimpulan sebagai berikut:

1. Pemanfaatan lahan di Kecamatan Sukajaya Kabupaten Bogor sebagian besar masih berupa hutan lindung, permukiman penduduk dan lahan belum terbangun. Lahan yang sesuai (kelas S1) untuk tanaman tanaman padi gogo (Oryza sativa L.) mencapai $0 \%$, untuk lahan yang cukup sesuai (S2) mencapai 19\%, untuk lahan yang sesuai marginal (S3) mencapai 17\%, serta lahan yang tidak sesuai $(\mathrm{N})$ mencapai 64\%. Berdasarkan data yang diperoleh, parameter yang digunakan dalam analisis kesesuaian lahan tanaman padigogo (Oryza sativa L.) adalah kemiringan lereng, ketinggian, penggunaan lahan, suhu, curah hujan, kelembaban, pH, Posfor, Kalium, dan C-Organik.

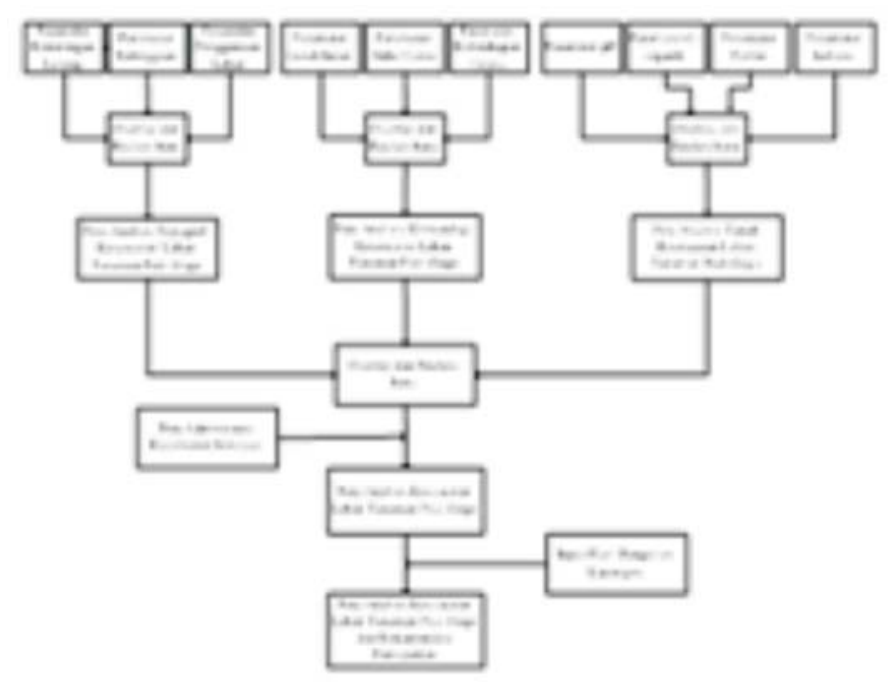

Gambar 1. Proses Analisis Overlay 
Tabel 1. Kandungan pH, P, K, C-Organik, dan Kapur pada tiap titik sampel

\begin{tabular}{|c|c|c|c|c|c|c|}
\hline \multirow{2}{*}{ No. } & \multirow{2}{*}{ ID Sampel } & \multicolumn{2}{|c|}{ Koordinat } & \multicolumn{3}{|c|}{ Rekomendasi Pemupukan } \\
\hline & & $\mathrm{X}$ & $\mathrm{Y}$ & SP36 (kg/ha) & Kalium (kgKCl/ha) & Bahan Organik (t/ha) \\
\hline 1 & S 01 & 659090 & 9268799 & 200 & 75 & 2 \\
\hline 2 & S 02 & 660169 & 9270614 & 200 & 50 & 1 \\
\hline 3 & S 03 & 660421 & 9270629 & 200 & 75 & 2 \\
\hline 4 & S 04 & 662762 & 9270591 & 200 & 75 & 2 \\
\hline 5 & S 05 & 663481 & 9267585 & 200 & 50 & 2 \\
\hline 6 & S 06 & 663038 & 9265556 & 150 & 50 & 2 \\
\hline 7 & S 07 & 662452 & 9263638 & 200 & 50 & 2 \\
\hline 8 & S 08 & 664090 & 9265840 & 150 & 75 & 2 \\
\hline 9 & S 09 & 661743 & 9269952 & 200 & 50 & 2 \\
\hline 10 & S 10 & 663277 & 9269407 & 200 & 50 & 2 \\
\hline 11 & S 11 & 657522 & 9274552 & 150 & 75 & 2 \\
\hline 12 & S 12 & 659438 & 9274629 & 200 & 75 & 2 \\
\hline 13 & S 13 & 660774 & 9274602 & 200 & 75 & 2 \\
\hline 14 & S 14 & 658147 & 9272794 & 200 & 75 & 2 \\
\hline 15 & S 15 & 659290 & 9272874 & 200 & 75 & 2 \\
\hline 16 & S 16 & 660760 & 9272215 & 200 & 75 & 2 \\
\hline 17 & S 17 & 658317 & 9271129 & 200 & 50 & 2 \\
\hline 18 & S 18 & 658123 & 9269400 & 200 & 50 & 2 \\
\hline 19 & S 19 & 659695 & 9267953 & 200 & 50 & 2 \\
\hline 20 & S 20 & 659594 & 9265676 & 200 & 50 & 2 \\
\hline 21 & S 21 & 660873 & 9267532 & 200 & 50 & 2 \\
\hline
\end{tabular}

Tabel 2. Rekomendasi pemupukan untuk tanaman Padi

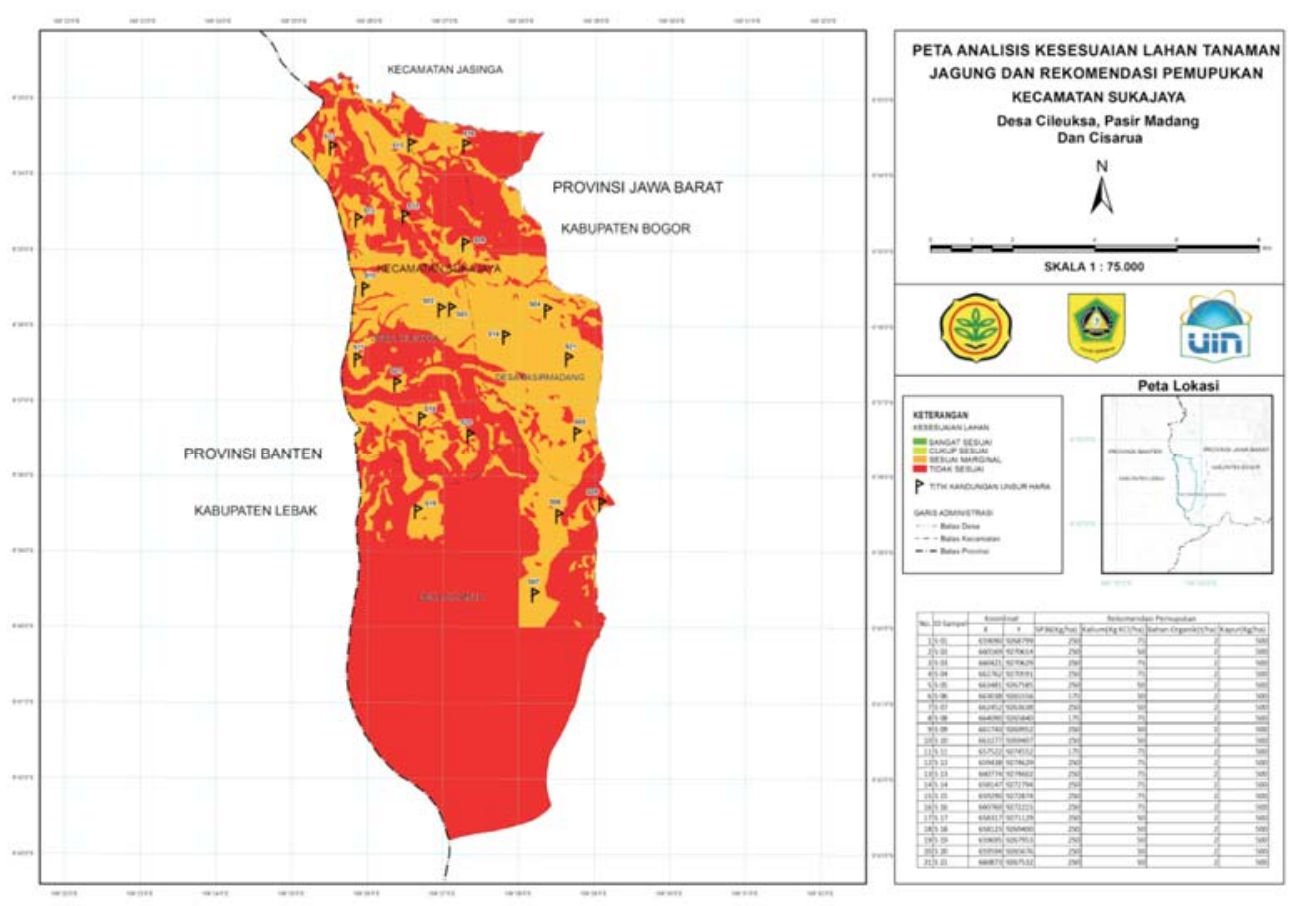

Gambar 2. Peta Kesesuaian Lahan Tanaman Padi Gogo 


\begin{tabular}{|c|c|c|c|c|c|c|c|c|}
\hline \multirow{2}{*}{ No. } & \multirow{2}{*}{$\begin{array}{c}\text { ID } \\
\text { Sampel }\end{array}$} & \multicolumn{2}{|c|}{ Koordinat } & \multicolumn{5}{|c|}{ Kandungan } \\
\hline & & $\mathrm{X}$ & $\mathrm{Y}$ & $\mathrm{pH}$ & $\mathrm{P}$ & $\mathrm{K}$ & C-Organik & Kapur \\
\hline 1 & S 01 & 659090 & 9268799 & Agak Masam & Rendah & Sedang & Rendah & $<4$ \\
\hline 2 & S 02 & 660169 & 9270614 & Masam & Rendah & Tinggi & Rendah & $<4$ \\
\hline 3 & S 03 & 660421 & 9270629 & Agak Masam & Rendah & Sedang & Rendah & $<4$ \\
\hline 4 & S 04 & 662762 & 9270591 & Agak Masam & Rendah & Sedang & Rendah & $<4$ \\
\hline 5 & S 05 & 663481 & 9267585 & Agak Masam & Rendah & Tinggi & Rendah & $<4$ \\
\hline 6 & S 06 & 663038 & 9265556 & Agak Masam & Sedang & Tinggi & Rendah & $<4$ \\
\hline 7 & S 07 & 662452 & 9263638 & Agak Masam & Rendah & Tinggi & Rendah & $<4$ \\
\hline 8 & S 08 & 664090 & 9265840 & Agak Masam & Sedang & Sedang & Rendah & $<4$ \\
\hline 9 & S 09 & 661743 & 9269952 & Agak Masam & Rendah & Tinggi & Rendah & $<4$ \\
\hline 10 & S 10 & 663277 & 9269407 & Agak Masam & Rendah & Tinggi & Rendah & $<4$ \\
\hline 11 & S 11 & 657522 & 9274552 & Agak Masam & Sedang & Sedang & Rendah & $<4$ \\
\hline 12 & S 12 & 659438 & 9274629 & Agak Masam & Rendah & Sedang & Rendah & $<4$ \\
\hline 13 & S 13 & 660774 & 9274602 & Agak Masam & Rendah & Sedang & Rendah & $<4$ \\
\hline 14 & S 14 & 658147 & 9272794 & Agak Masam & Rendah & Sedang & Rendah & $<4$ \\
\hline 15 & S 15 & 659290 & 9272874 & Agak Masam & Rendah & Sedang & Rendah & $<4$ \\
\hline 16 & S 16 & 660760 & 9272215 & Agak Masam & Rendah & Sedang & Rendah & $<4$ \\
\hline 17 & S 17 & 658317 & 9271129 & Agak Masam & Rendah & Tinggi & Rendah & $<4$ \\
\hline 18 & S 18 & 658123 & 9269400 & Agak Masam & Rendah & Tinggi & Rendah & $<4$ \\
\hline 19 & S 19 & 659695 & 9267953 & Agak Masam & Rendah & Tinggi & Rendah & $<4$ \\
\hline 20 & S 20 & 659594 & 9265676 & Masam & Rendah & Tinggi & Rendah & $<4$ \\
\hline 21 & S 21 & 660873 & 9267532 & Masam & Rendah & Tinggi & Rendah & $<4$ \\
\hline
\end{tabular}

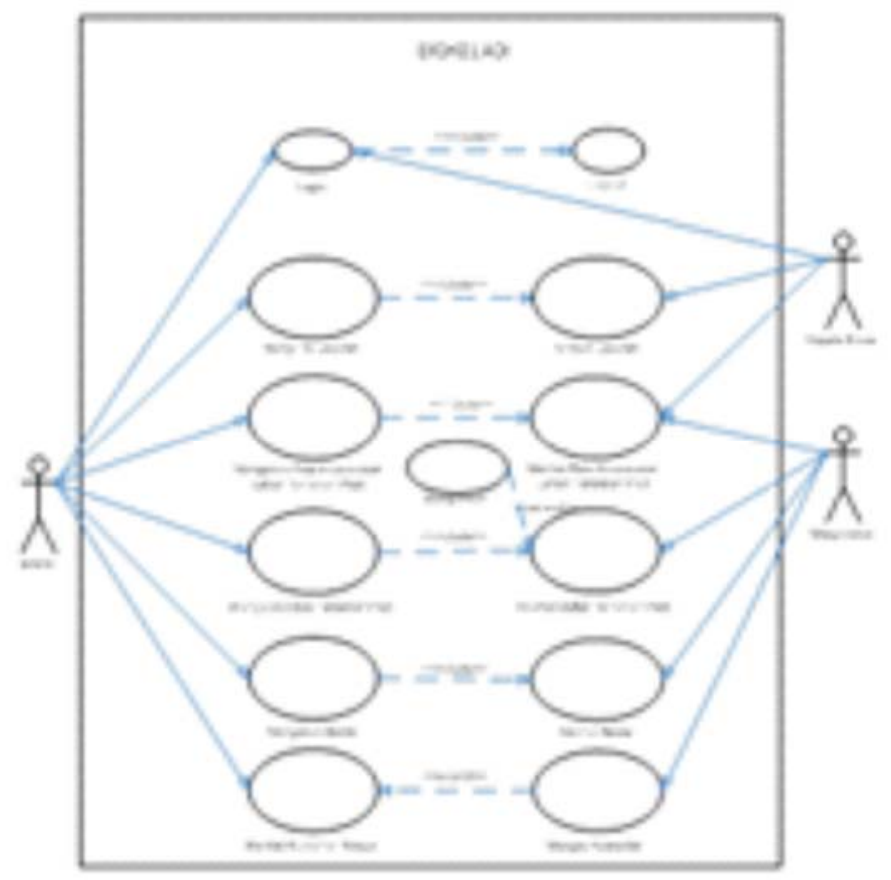

Gambar 3. Diagram Use Case 


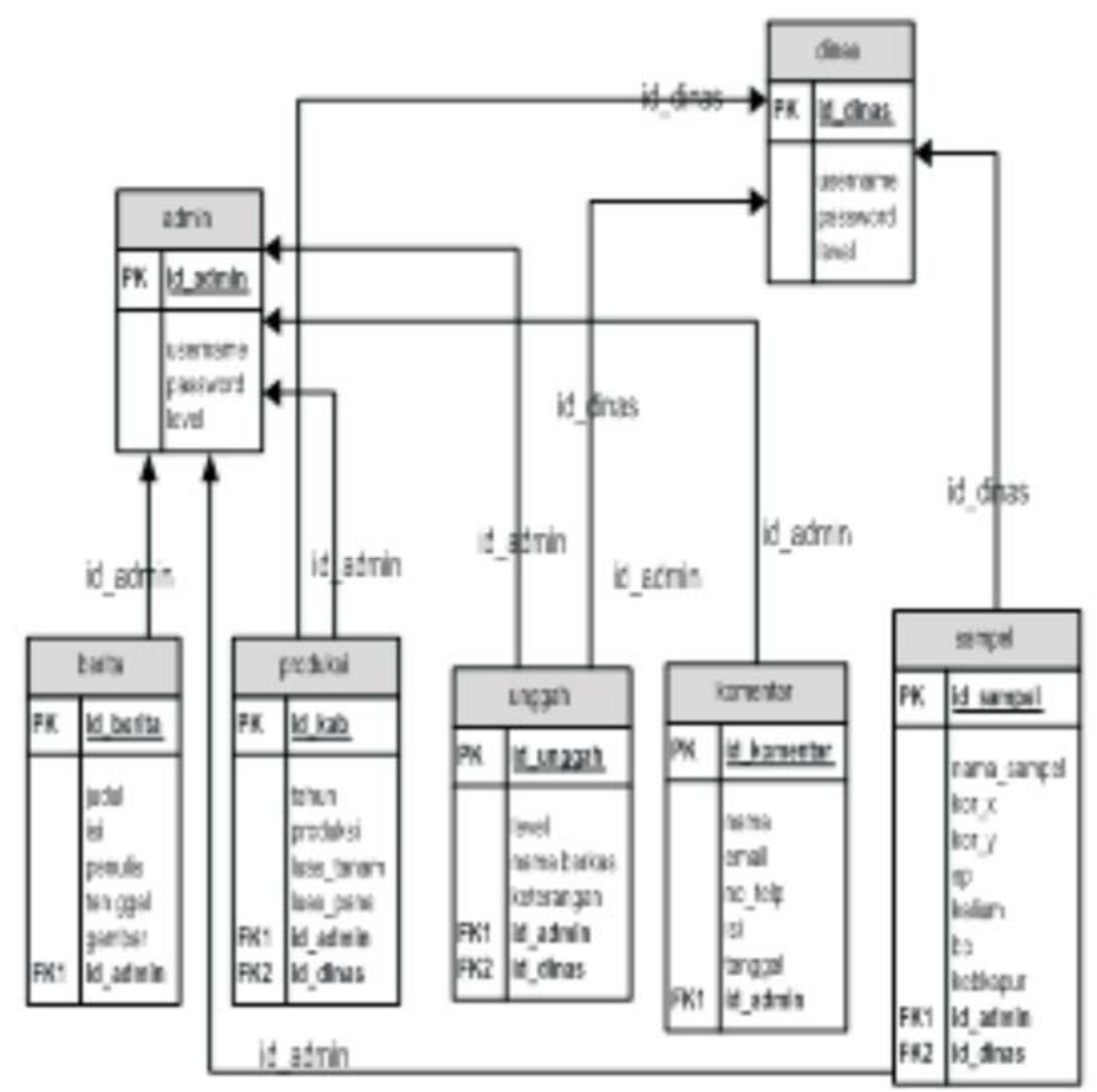

Gambar 4. Mapping Diagram Kelas

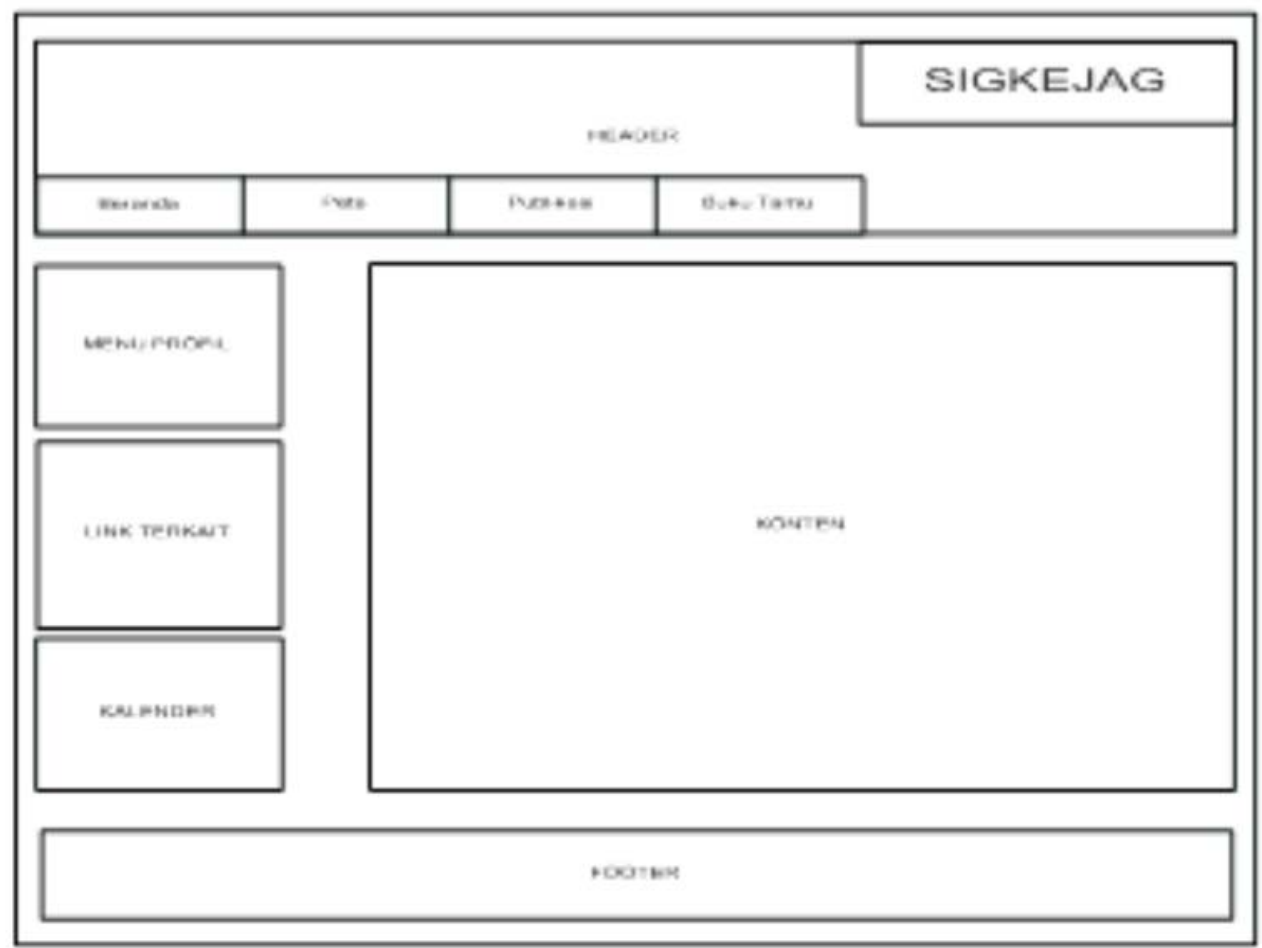

Gambar 5. Tampilan Layar Utama SIGKEJAG 
Setelah kesepuluh parameter tersebut dianalisis, kemudian dilakukan penelitian di 21 titik sampel yang hasilnya berupa kandungan unsur $\mathrm{pH}$, P, K, dan C-Organik. Selanjutnya dari hasil penelitian di 21 titik sampel tersebut didapatlah rekomendasi pemupukan di tiap-tiap titik sampel.

2. Menyediakan layanan informasi data kesesuaian lahan dan produksi tanaman Padi Gogo bagi masyarakat. b.) Dengan sistem informasi geografis ini maka penyampaian informasi spasial mengenai kesesuaian lahan tanaman padi gogo (Oryza sativa L.) maupun non spasial juga dapat disajikan dalam bentuk tampilan peta interaktif dan tabel yang lebih baik dan mudah dimengerti sehingga informasi kesesuaian lahan tanaman padi gogo (Oryza sativa L.) dapat diinformasikan dengan baik kepada masyarakat. Dan dengan sistem ini, diharapkan dapat memudahkan

DISTANHUT

Kabupaten Bogor di dalam mengatur data/informasi spasial maupun non spasial dari setiap laporan.

Dan berdasarkan hasil penelitian kesesuaian lahan di Kecamatan Sukajaya maka komoditas tanaman Padi Gogo paling unggul dari tanaman Jagung dan Kedelai. Berikut hasilnya :

- $\quad$ Padi Gogo : S1 = 0\%, S2 = 19\%, S3 $=17 \%$, dan $\mathrm{N}=64 \%$.

- $\quad$ Jagung : $\mathrm{S} 1=0 \%, \mathrm{~S} 2=0 \%, \mathrm{~S} 3=$ $36 \%, \mathrm{~N}=64 \%$.
- $\quad$ Kedelai : $\mathrm{S} 1=0 \%, \mathrm{~S} 2=0 \%, \mathrm{~S} 3=$ $0 \%, \mathrm{~N}=100 \%$

Maka tanaman Padi Gogo bisa dijadikan andalan pada tanaman pangan di Kecamatan Sukajaya dan sehingga ke depan produksi padi gogo di Kecamatan Sukajaya bisa membantu untuk dijadikan andalan produksi padi nasional.

\section{Saran}

Dikarenakan adanya keterbatasan dalam pelaksanaannya, maka penelitian ini mempunyai kelemahan yang dapat dijadikan sebagai bahan pertimbangan dalam penelitian lanjut. Adapun saran-saran yang dapat penulis berikan adalah:

1. Setelah dilakukan penelitian Di desa Cileuksa, Pasir Madang, dan Cisarua. Maka didapatkanlah hasil analisis yaitu Cukup Sesuai, Sesuai Marginal dan Tidak Sesuai, Oleh karena itu penulis menyarankan apabila ingin mendapatkan hasil yang maksimal di lokasi yang cukup sesuai maka memerlukan tambahan masukan (input) dan hal tersebut dapat diatasi oleh petani sendiri. Kemudian jika ingin mendapatkan hasil yang maksimal di lokasi yang sesuai marginal maka diperlukan modal tinggi sehingga perlu adanya bantuan atau campur tangan (intervensi) dari pemerintah atau pihak swasta.

2. Untuk Rekomendasi pemupukan di desa Cileuksa, Pasir Madang dan Cisarua disarankan rata-rata pupuk SP36 adalah $200 \mathrm{Kg} / \mathrm{ha}$, Kalium 
sebesar 50 - $75 \mathrm{Kg} \mathrm{KCl} \mathrm{/} \mathrm{ha,} \mathrm{dan} \mathrm{Bahan}$

Organik $2 \mathrm{t} / \mathrm{ha}$.

\section{DAFTAR PUSTAKA}

BPS [Badan Pusat Statistik] Kabupaten Bogor. 2013. Angka Sementara Hasil Sensus Pertanian 2013. BPS. Kabupaten Bogor.

Dinas Pertanian dan Kehutanan.2010. Monografi Pembangunan Pertanian dan Kehutanan. Kabupaten Bogor: Distanhut.

Djaenudin, D., Marwan, H., Subagjo, H., dan A. Hidayat. 2011. Petunjuk Teknis Evaluasi Lahan Untuk Komoditas Pertanian. Balai Besar Penelitian Tanah Dan Pengembangan Sumberdaya Lahan Pertanian. Bogor.

FAO. 1976. A Framework for Land Evaluation. Soil Resources Management and Conservation Service Land and Water Development Division.FAO Soil Bulletin No.32.FAO-UNO, Rome.

Hardjowigeno, S. dan Widiatmaka. 2007. Evaluasi Kesesuaian Lahan dan Perencanaan Tataguna Lahan.Gadjah Mada University Press. Yogyakarta.

Kendall. 2008. Analisis dan perancangan sistem. Indeks, Jakarta.

Norsalis, E. 2011. Tinjauan Secara Morfologi, Budidaya, dan Fisiologi Padi Gogo dan Sawah.http://skp.unair.ac.id/repo sitory/Guru-
Indonesia/Padigogodansawah_e

konorsalis_17170.pdf.

Desember 2013].

OpenGeo Suite. 2009. OpenGeo. http://www.opengeo.org[ 21 November 2013].

Prahasta, Eddy. 2005. Sistem Informasi Geografis: Konsep-konsep Dasar Informasi Geografis. Informatika. Bandung.

Prahasta, Eddy. 2007. Membangun Aplikasi Web-based GIS dengan Mapserver.

Informatika.Bandung.

Pujiharti, Yulia. Barus, Junita. Wijayanto, Bambang. 2008. Teknologi Budidaya Padi. ISBN: 978-9791415-22-4. Badan Penelitian Dan Pengembangan Pertanian. Bogor.

Santosa, Andri., Y., Sukandar, E.K., dan Nurhawan, R. 2003. Analisa Terhadap Beberapa Peraturan Desa Di Kecamatan Sukajaya dan Kecamatan Nanggung Kabupaten Bogor - Propinsi Jawa Barat. Huma. Jakarta.

Setyorini, Diah. Nurjaya. Widowati, LR. Kasno, A. 2007.Perangkat Uji Tanah Kering (Upland Soil Test Kit) Versi 1.0: Balai Penelitian Tanah, Balai Besar Litbang Sumberdaya Lahan Pertanian. Bogor.

Toha, M. H. 2011. Pengembangan Padi Gogo Mengatasi Rawan Pangan Wilayah Marginal.http://www.litbang.per tanian.go.id/buku/Lahan-Kering- 
Ketahan/BAB-III-4.pdf

$[25$

Oktober 2014]

Whitten, J.L., Bentley, L.D dan Dittman, K.C. 2004. Metode Desain \&
Analisis Sistem Edisi 6. ANDI \&

Mc Graw Hill Education.

Yogyakarta

* Alumni dan **Dosen Prodi Sistem Informasi; ***Dosen Program Studi Agribisnis, FST UIN Syarif Hidayatullah Jakarta (Email: brian.armadji@gmail.com) 
